\title{
CAUSATION IN TORT LAW: \\ BACK TO BASICS AT THE SUPREME COURT OF CANADA
}

\author{
MITCHELL MCINNES ${ }^{\circ}$
}

This article analyzes the role of causation in Canadian tort law. The author uses the recent Supreme Court of Canada decision of Athey $v$. Leonati as a model to show how even complex problems of causation can be solved through the application of fundamental principles of tort law: the "restoration" principle, the "lake your victim" principle, and the "vicissitudes" principle. The author also demonstrates the importance of distinguishing types of causes based on the following dichotomies: tortious and non-tortious, sufficient and insufficient, and simultaneous and successive. The author argues that applying these principles, and distinguishing causes in this manner, will greatly simplify the resolution of even seemingly complex problems of causation in tort law.
$L$ 'aureur analyse le röle de la causalité dans les règles de droit applicables aux préjudices au Canada. Il utilise la décision récente de la Cour supreme du Canada dans Athey c. Leonati pour montrer comment résoudre des problèmes de causalité complexes à l'aide de certains principes fondamentaux : le principe de rétablissement là la situation originale]. le principe de la vulnérabilité de la victime et le principe des vicissitudes. $L$ 'auteur démontre qu'il est important de distinguer les cas d'après les dichotomies suivantes: préjudiciable et non préjudiciable, suffisant et insuffisant, simultane et successif. II soutient que l'application de ces principes et de ces distinctions simplifie considérablement la résolution de problèmes de causalité qui semblent pourtant très complexes dans ce domaine du droit.

\section{TABLE OF CONTENTS}

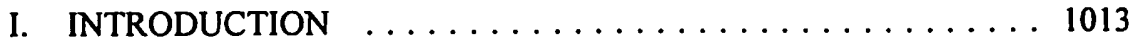

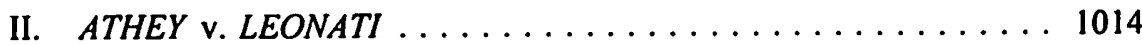

A. THE BRITISH COLUMBIA SUPREME COURT . . . . 1015

B. THE BRITISH COLUMBIA COURT OF APPEAL . . . . 1015

C. THE SUPREME COURT OF CANADA ......... 1016

III. A RESTATEMENT OF THE RULES OF CAUSATION . . . . 1017

A. MULTIPLE CAUSES $\ldots \ldots \ldots \ldots \ldots \ldots \ldots 1018$

B. THIN SKULLS AND CRUMBLING SKULLS $\ldots \ldots \ldots 1030$

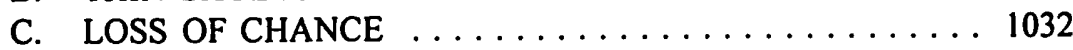

IV. CONCLUSION $\ldots \ldots \ldots \ldots \ldots \ldots \ldots \ldots \ldots \ldots \ldots \ldots \ldots$

\section{INTRODUCTION}

Causation leads something of a double life in tort law. In academic circles, it is the subject of great sophistication and the source of endless debate.' Indeed, given the scientific, philosophical and political issues involved, it would be surprising if the situation were otherwise. By contrast, in judicial circles, causation is approached in a

Ph.D. (Cambridge); Faculty of Law, University of Western Ontario. I would like to thank Alison Hughes and Lorenz Berner for their helpful comments on an earlier draft of this article.

I See e.g. H.L.A. Hart \& T. Honoré, Causation in the Law, 2d ed. (Oxford: Clarendon Press, 1985); L. Green, "The Causal Relation Issue in Negligence Law" (1962) 60 Mich. L. Rev. 543; W. Malone, "Ruminations on Cause-In-Fact" (1956) 9 Stan. L. Rev. 60; R. Wright, "Causation in Tort Law" (1985) 73 Calif. L. Rev. 1737; R. Epstein, "A Theory of Strict Liability" (1973) 2 J. Leg. Stud. 151; S. Pincus, "Progress on the Causal Chain Gang: Some Approaches to Causation in Tort Law and Steps Toward a Linguistic Analysis" (1986) 24 Osgoode Hall L.J. 961. 
simpler and less contentious manner. While some areas of genuine uncertainty remain, common sense is the agreed touchstone and the basic rules largely are settled. Of course, that is not to say that the courts invariably decide cases correctly; not infrequently, mistakes are made and liability improperly is denied or imposed. Nevertheless, it is true that most errors are readily avoidable.

The judicial history of Athey v. Leonati ${ }^{2}$ illustrates that proposition. As discussed below, the British Columbia Supreme Court and Court of Appeal misapprehended the applicable rules and consequently deprived the claimant of relief to which he legally was entitled. By returning to first principles, however, the Supreme Court of Canada easily was able not only to correct the errors committed below, but also to indicate the means by which lower courts may avert similar mistakes in the future. Indeed, following that decision, it is the thesis of this article that the vast majority of causal problems in tort law can be resolved without great difficulty by consistently applying a small number of rudimentary principles within the context of an organizing scheme.

\section{ATHEY v. LEONATI}

In 1991, Jon Athey was a 43 year old autobody repairman and bodyshop manager with a susceptibility to back problems and a string of bad luck. In February of that year, he was involved in a motor vehicle accident that demolished his car and left him with a stiff back and neck. After four days of rest, he was able to return to work, but found it necessary to concentrate less on physical labour and more on managerial duties. In late April, when seemingly on his way to recovery, he was involved in another motor vehicle accident. While able to return to work the next day, he again was required to undertake less heavy work and more managerial responsibilities. Over the course of the summer, he received physiotherapy and chiropractic treatment, and by autumn his condition had improved to the point where his doctor advised him to commence a regular exercise routine. Athey dutifully attended upon "Fitness World," but, his fortunes being what they were, his visit was frustratingly brief. During warm-up stretches, he felt a sudden "pop" in his lower back and immediately experienced a great deal of pain. He managed to hobble home, but by morning was unable to move. After three weeks of hospitalization and several months of wishful thinking, he underwent surgery for a disc herniation. The outcome of the procedure was "good, but not excellent." Consequently unable to resume his former responsibilities, Athey found it necessary to enter an alternative form of employment at a lower rate of pay.

In an effort to recover his losses, Athey instituted claims against the drivers responsible for the two traffic accidents. Though mixed, his luck generally continued to run cold. On the positive side, the defendants admitted liability and conceded that there was no issue of contributory negligence. Moreover, because both defendants were represented by the same insurer, the parties agreed to proceed as if there had been only one motor vehicle collision. On the negative side, however, Athey had the misfortune 
of seeking relief in British Columbia courts that apparently were unfamiliar with the basic rules of causation.

\section{A. THE BRITISH COLUMBIA SUPREME COURT}

At trial, Boyd J. properly identified the issue to be:

Whether the injuries suffered in the two motor vehicle accidents contributed to the plaintiff's present symptoms or whether those symptoms are the ongoing sequelae of the disc hemiation and subsequent discectomy and whether the latter resulted from or are in any way related to the earlier soft tissue injuries suffered in the motor vehicle accidents. ${ }^{3}$

Seemingly, she found for the plaintiff.

I am satisfied that the injuries suffered in the two motor vehicle accidents are not the sole cause of the plaintiff's ongoing complaints. Likewise, I reject the defence theory that the disc hemiation and subsequent discectomy are not causally related in any way to the injuries suffered in the earlier motor vehicle accidents. Weighing the evidence as a whole, I am satisfied that the injuries suffered in the earlier accidents played some causative role, albeit a minor one, in the eventual disc herniation. ${ }^{4}$

However, while that finding should have led to her to award full damages, she then went on to say:

While it may perhaps be somewhat arbitrary, 1 find that it is fair and reasonable in all of the circumstances, if not somewhat generous to the plaintiff, to assess the two motor vehicle accidents as being $25 \%$ responsible for the eventual disc protrusion. I will ... award $25 \%$ of the global damage award to the plaintiff, as being those damages attributable to the two accidents.'

\section{B. THE BRITISH COLUMBIA COURT OF APPEAL}

Athey fared no better in the Court of Appeal. In a brief, oral judgment, Southin J.A. (Rowles \& Prowse JJ.A. concurring) quickly reviewed the facts and dismissed the appeal.

In this Court, counsel for the appellant, who was not counsel below, has put before us a most interesting argument founded on the judgments of the House of Lords in McGhee v. National Coal Board and Bonnington Castings Lıd. v. Wardlaw, that the findings of the learned trial judge required her as a matter of law to award to the plaintiff 100 percent of the damages (using that word loosely) which would be attributable to the defendants if, in fact, they or one of them had caused the disc herniation. Unfortunately, it is plain to us that the application of those authorities, and more particularly the meaning of the phrase in them of "material contribution," was never put to the learned trial judge.

$3 \quad$ Athey v. Leonati (B.C.S.C.), supra note 2 at para. 2.

$4 \quad$ Ibid. at para. 15 . See also paras. 3-4.

s Ibid. at para. 21. 
In my view, it would not be appropriate for us to address a theory of liability for the disc herniation which was not advanced before the learned trial judge who was not, in my view, in her reasons for judgment addressing the concepts of those authorities. ${ }^{6}$

\section{THE SUPREME COURT OF CANADA}

Just when hope must have been all but exhausted, Athey's fortunes finally changed at the Supreme Court of Canada. First, he was granted leave to appeal on an application that might have been expected to fail. ${ }^{7}$ As its governing statute stresses, the Supreme Court is not a court of error; its function generally is to settle matters of national importance, not to ensure justice in the context of individual disputes. ${ }^{8}$ And, notwithstanding the mistakes committed by the lower courts, the rules governing Athey's dispute were well established. Second (and much less surprising once he had been granted leave), Athey was awarded 100 percent of his damages. ${ }^{9}$

Major J., writing for a unanimous court, began by restating fundamental rules. First, to succeed in an action in negligence, the plaintiff generally must prove the issue of causation on a balance of probabilities. ${ }^{10}$ Second, causation typically is established on the basis of the "but for" test: if, "but for" the defendant's carelessness, the plaintiff would not have suffered the loss" in question, a sufficient causal connection exists. ${ }^{12}$ Third, however, the plaintiff need not prove that such carelessness was the only relevant causal factor. It is sufficient to establish that the defendant's conduct "materially contributed" (beyond the de minimis range) to the creation of the injury. ${ }^{13}$

It is not now necessary, nor has it ever been, for the plaintiff to establish that the defendant's negligence was the sole cause of the injury. There will frequently be a myriad of other background events which are necessary preconditions to the injury occurring.... As long as a defendant is part of the cause of an injury, the defendant is liable, even though his act alone was not enough to create the

Athey v. Leonati (B.C.C.A.), supra note 2 at paras. 8-9 [citations omitted].

Athey v. Leonati, [1995] 4 S.C.R. v.

Supreme Court Act, R.S.C. 1985, c. S-26, s. 40(1).

Athey v. Leonati (S.C.C.), supra note 2.

Snell v. Farrell, [1990] 2 S.C.R. 311 [hereinafter Snell]; McGhee v. National Coal Board, [1972] 3 All E.R. 1008 (H.L.) [hereinafter McGhee]. Exceptionally, the standard is not so exacting (Cook v. Lewis, [1951] S.C.R. 830).

Though the terms commonly are used interchangeably, a distinction can be drawn between an "injury" and a "loss." The former refers to the physical, psychological or property damage sustained by the plaintiff. The latter refers to the adverse economic consequences of an injury (e.g. loss of earning capacity, medical expenses). Relief in tort law is awarded to compensate for losses, not injuries (Sunrise Co. v. The Lake Winnipeg, [1991] 1 S.C.R. 3 [hereinafter Sunrise]).

Horsley v. McLaren, [1972] S.C.R. 441. However, the converse does not invariably hold true. As discussed in the next part, some factors that cannot satisfy the "but for" test nevertheless may be of determinative causal significance for the purposes of an action in tort.

Myers v. Peel County Board of Education, [1981] 2 S.C.R. 21; School Division of Assiniboine South No. 3 and Hoffer v. Greater Winnipeg Gas Co., [1971] 4 W.W.R. 746 (Man. C.A.), aff'd [1973] S.C.R. vi; Bonnington Castings Lid. v. Wardlaw, [1956] 1 All E.R. 615 (H.L.); McGhee, supra note 10. 
injury. There is no basis for a reduction of liability because of the existence of other preconditions: defendants remain liable for all injuries caused or materially contributed to by their negligence. ${ }^{14}$

Finally, causation essentially is a matter of common sense; it need not be proved to a scientific standard and in some circumstances may be inferred on the basis of relatively little evidence. ${ }^{15}$

Having reiterated those basic rules of causation, Major J. experienced no difficulty resolving the appeal in Athey's favour. After careful review, he interpreted Boyd J.'s trial judgment to mean that Athey's disc herniation was caused 75 percent by the effect of a latent weakness in his back and 25 percent by the effects of the two traffic accidents. On the basis of the preceding principles, the traffic accidents consequently provided a "material contribution" to the ultimate injury and therefore should have resulted in the defendants being held liable for all of the plaintiff's losses. The trial judge's failure to so hold constituted an error of law. So too did the Court of Appeal's refusal to entertain the "most interesting argument" raised by Athey's appellate counsel to the effect that proof of a material contribution prima facie entitled the plaintiff to 100 percent of his damages. As Major J. noted, whatever Southin J.A. intended by that phrase, the appellant's theory of liability certainly was not novel; indeed, it represented orthodox principles. ${ }^{16}$ Moreover, given that all of the relevant evidence was in the record, and given that the defendants' position at trial (i.e. that the disc herniation was entirely unrelated to the motor vehicle accidents) undoubtedly would have been the same even if Athey's trial counsel had argued the issue of material contribution, the Court of Appeal was bound to resolve what amounted to a question of pure law. ${ }^{17}$

\section{A RESTATEMENT OF THE RULES OF CAUSATION}

On the basis of a handful of rudimentary rules, Major J. easily was able to resolve the relatively simple causal problem in Athey v. Leonati. Moreover, as he suggested in dicta, even more complex problems easily can be answered to a satisfactory legal (if not scientific or philosophical) standard if a small number of fundamental principles also are borne in mind.

The most fundamental of all tort law principles requires the defendant to restore the plaintiff to the position that he enjoyed before she wrongfully subjected him to a loss. $^{18}$ The claimant's status quo ante consequently provides the standard against which both liability and relief are measured. If the defendant's conduct worsened the plaintiff's condition, then she must compensate him to the extent that he was harmed. No more and no less: she is not required to improve his lot in life, nor is she permitted

$14 \quad$ Athey v. Leonati (S.C.C.), supra note 2 at 467 (para. 17).

is Snell, supra note 10; Alphacell v. Woodward, [1972] 2 All E.R. 475 (H.L.).

16 Athey v. Leonati (S.C.C.), supra note 2 at 468 (para. 20).

17 J. Sopinka \& M. Gelowitz, The Conduct of An Appeal (Toronto: Butterworths, 1993) at 51.

18 For ease of discussion, when speaking in the abstract, this article will use female pronouns for defendants and male pronouns for plaintiffs. 
to leave him adversely affected. ${ }^{19}$ From that basic principle flow two subsidiary principles. The first holds that the defendant must take her victim as she finds him. That rule cuts both ways. It means that the defendant generally cannot avoid liability on the basis that the (extent of the) plaintiff's loss partially was attributable to the fact that he had a pre-existing susceptibility to harm. ${ }^{20}$ But it also means that the defendant need not compensate the plaintiff for losses that he had suffered before she acted wrongfully. The second subsidiary principle essentially applies the same reasoning prospectively, rather than retrospectively. In some circumstances, the plaintiff cannot recover compensation for losses caused by the defendant's wrongful conduct if he subsequently (would have) suffered the same loss by reason of another causal factor. ${ }^{21}$ Typically, that principle is applied speculatively to the quantification of damages to reflect the contingencies of life that might affect the claimant after trial. ${ }^{22}$ If, however, the contingency in question manifests itself prior to trial, the court will take it into account as a matter of fact, rather than speculation. ${ }^{23}$ For ease of discussion, those principles will be referred to respectively as: (i) the "restoration" principle, (ii) the "take your victim" principle, and (iii) the "vicissitudes" principle.

\section{A. MULTIPLE CAUSES}

Generally speaking, the most taxing causal issues arise under the rubric of "multiple causation." However, even they can be resolved without great difficulty by means of common sense application of the preceding rules and principles. A number of situations stand to be examined. ${ }^{24}$

Of course, that ideal often is unfulfilled. For example, the speculative nature of damages for loss of future earnings almost invariably results in either under-compensation or over-compensation. That rule finds expression in the "thin skull" doctrine: discussed below at Part III(B).

Similarly, subsequent events affecting the plaintiff may result in a reduction of damages if they diminish the losses suffered (e.g by facilitating unexpected recuperation) or shorten the period during which losses will be incurred (e.g. by hastening death). See Jobling v. Associated Dairies Ltd., [1982] A.C. 794 at 814 (H.L.) [hereinatter Jobling]; Baker v. Willoughby, [1970] A.C. 467 at 493 (H.L.) [hereinafter Baker].

While contingencies typically are thought of as being negative, they may be positive; the claimant's condition may either worsen or improve in time (Lewis v. Todd and McClure, [1980] 2 S.C.R. 694 at 714; Andrews v. Grand \& Toy Alberta Ltd., [1978] 2 S.C.R. 229 at 253). Courts accordingly may either increase or decrease damages to reflect possible, future events. See generally $K$. Cooper-Stephenson, Personal Injury Damages in Canada, 2d ed. (Toronto: Carswell, 1996) at 375-94.

23 Again, the event in question may be positive in nature. For example, the plaintiff may, before trial, experience an event that facilitates a miraculous recovery from the effects of the defendant's wrongdoing. If so, he will receive less compensation than he would have if his recuperation had followed the normal course. Generally, however, the plaintiff's condition is negatively affected by the second event and it is with that type of situation that this article is concerned.

Because much of the confusion surrounding causal issues results from a failure to properly characterize and distinguish different fact patterns, the following examination proceeds rather mechanically. What that approach lacks in stylistic subtlety, it hopefully enjoys in clarity. 


\section{Multiple Insufficient Causes}

Considering the simplest situations first, an injury can be said to be the product of "multiple insufficient causes" if it is the result of several causal factors, all of which were necessary, and none of which independently was sufficient, for its occurrence. Two possibilities exist.

\section{a. Tortious and Non-Tortious Causes}

The first possibility occurs when an injury is the result of both tortious and non-tortious causes, neither of which independently were capable of producing the harm in question. Of course, that arguably is true of all negligently inflicted injuries; every event is the outcome of innumerable factors. Thus, to borrow an illustration from Fleming, by way of Major J., "a fire ignited in a wastepaper basket is ... caused not only by the dropping of a lighted match, but also by the presence of combustible material and oxygen, a failure of the cleaner to empty the basket and so forth." 26

Fleming's example would be even more instructive for present purposes if mention of the cleaner's conduct was omitted. ${ }^{27}$ In that event, surely no lawyer would hesitate in attributing causal responsibility to the actor who (presumably) carelessly dropped the lighted match. The presence of oxygen would not present analytical difficulties because it would be recognized (if at all) as merely being part of the environment within which the tortfeasor acted. While perhaps less obvious, precisely the same was true in Athey v. Leonati. ${ }^{28}$ Although the lower courts failed to appreciate the point, Major $\mathrm{J}$. correctly characterized the latent weakness in the plaintiff's back simply as part of the circumstantial matrix within which the defendants' carelessness created a loss. Moreover, he explained that characterization with reference to the "restoration" principle:

If the law permitted apportionment between tortious causes and non-tortious causes, a plaintiff could recover 100 percent of his or her loss only when the defendant's negligence was the sole cause of the injuries. Since most events are the result of a complex set of causes, there will frequently be non-tortious causes contributing to the injury. Defendants could frequently and easily identify non-tortious contributing causes, so plaintiffs would rarely receive full compensation even after proving that the defendant caused the injury. This would be contrary to established principles and the essential purpose of tort law, which is to restore the plaintiff to the position he or she would have enjoyed but for the negligence of the defendant. ${ }^{29}$

Athey v. Leonati (S.C.C.), supra note 2 at 467 (para. 17).

J.G. Fleming, The Law of Torts, 8th ed. (Sydney: Law Book, 1992) at 193.

The cleaner's role raises the possibility that the fire was the result of two tortious causes: the careless housekeeping and the careless disposal of the match. That possibility is examined below at Part $\operatorname{III}(A)(1)(b)$.

One potential difference between the two situations is that while the presence of oxygen alone can never result in a fire, the presence of pre-existing back problems alone can result in a disc herniation. However, Major J. rejected that possibility on the facts of Athey v. Leonati (below at Part III(B)).

Athey v. Leonati (S.C.C.), supra note 2 at 468 (para. 20). 


\section{b. Tortious Causes}

The analysis remains relatively simple when both necessary, independently insufficient causes are tortious. In the celebrated Australian case of Chapman v. Hearse, ${ }^{30}$ Chapman carelessly injured himself in a motor vehicle accident. Dr. Cherry stopped at the scene to render medical assistance, but was killed when struck by a car negligently driven by the aptly named Hearse. Because each defendant's conduct was a "but for" cause of the resulting losses, both Chapman and Hearse were held liable to Dr. Cherry's estate. ${ }^{31}$ In such situations, the plaintiff may look to either defendant for all of his damages or he may partially recover from each. ${ }^{32}$ As between themselves, tortfeasors may rely upon apportionment legislation to seek contribution from one another to ensure that the burden of liability eventually is shared appropriately. ${ }^{33}$

In Athey v. Leonati, the defendants sought to avoid full liability by arguing that just as the courts will apportion responsibility between two tortious causes, neither of which independently was capable of producing the loss in question, so too they should apportion responsibility between two causes, one tortious and the other non-tortious, neither of which independently was sufficient. That proposition received suitably short shrift from Major J. Once again, the restoration principle provided a complete answer.

The two situations are not analogous. Apportionment between tortious causes is expressly permitted by provincial negligence statutes and is consistent with the general principles of tort law. The plaintiff is still fully compensated and is placed in the position he or she would have been in but for the negligence of the defendants. Each defendant remains fully liable to the plaintiff for the injury, since each was a cause of the injury. The legislation simply permits defendants to seek contribution and indemnity from one another, according to the degree of responsibility for the injury.

In the present case, the suggested apportionment is between tortious and non-tortious causes. Apportionment between tortious and non-tortious causes is contrary to the principles of tort law, because the defendant would escape full liability even though he or she caused or contributed to the

(1961) 106 C.L.R. 112 (Aust. H.C.). The same principle has been applied less colourfully in Canadian cases (see e.g. Jordan House Led. v. Menow, [1974] S.C.R. 239).

While the causal factors typically occur more or less simuitaneously and result in only one injury, the causes may be substantially separated in time and involve multiple (or exacerbated) injuries. Thus, if the first tortfeasor causes an initial injury that subsequently is exacerbated by negligent medical care, both defendants may be held liable for the additional losses (although only the first will be held for losses that would have been sustained regardless of the mistreatment). See Katzman v. Yaeck (1982), 136 D.L.R. (3d) 536 (Ont. C.A.); Watson v. Grant (1970), 72 W.W.R. 665 (B.C.S.C.). However, in some situations, the court may hold that the subsequent misconduct severed the causal chain that began with the first cause and culminated in the loss in question. If so, the initial tortfeasor will be relieved of responsibility for the plaintiff's exacerbated condition (although, again, she will remain liable for losses that would have been sustained regardless of the second event). See Kolesar v. Jeffries (1974), 9 O.R. (2d) 41 (H.C.J.); and cf. Mercer v. Gray, [1941] 3 D.L.R. 564 (Ont. C.A.). (That principle of novus actus interveniens arises at the remoteness stage of the negligence analysis and will not be considered in this comment. See generally L.N. Klar, Tort Law, 2d ed. (Toronto: Carswell, 1996) at 350-59.) recover in total an amount that exceeds of the value of his claim. 
plaintiff's entire injuries. The plaintiff would not be adequately compensated, since the plaintiff would not be placed in the position he or she would have been in absent the defendant's negligence. ${ }^{34}$

In a variation on the same theme, the defendants argued that just as the courts attribute responsibility for divisible injuries to individual tortfeasors, so too the courts attribute responsibility for divisible injuries between tortious and non-tortious causes. Of course, both parts of that proposition are absolutely true. If one tortfeasor breaks the claimant's arm and another tortfeasor breaks the claimant's leg, then (assuming that there is no causal relationship between the two injuries) each defendant is fully liable only for the losses that she inflicted. ${ }^{35}$ Likewise, if the claimant's arm is broken by the defendant's carelessness and his leg is broken by some non-tortious cause, the defendant is fully liable only for the former injury. ${ }^{36}$ However, as Major J. recognized, neither of those propositions was relevant in the circumstances of Athey v. Leonati. Regardless of the fact that the motor vehicle accidents occurred during the winter and spring, the pertinent losses all arose following the Fitness World incident in the autumn. Consequently, as there was only one relevant injury - the disc herniation - there was no question of divisible injuries. ${ }^{37}$

\section{Multiple Sufficient Causes}

The analysis becomes noticeably more complex in cases of "multiple sufficient causation" in which each of the competing causes independently was capable of producing the loss in question. In such circumstances, the "but for" test often fails to provide a satisfactory answer. Looking at each factor in isolation, it cannot be said that the loss would not have occurred "but for" that cause; even if the first cause had not occurred, the second cause would have created the same outcome, and vice versa. In some situations, the conclusion that neither factor constitutes a culpable cause is unacceptable. Fortunately, the courts refuse to allow causal over-determination to frustrate the basic aims of tort law. By means of common sense applications of the three principles noted above, they (generally) arrive at appropriate conclusions.

\section{a. Tortious and Non-Tortious Causes}

Once again, the simpler set of cases arises when one of the competing causes is tortious and the other is non-tortious. In such circumstances, application of the "but for"

34 Athey v. Leonati (S.C.C.), supra note 2 at 469 (paras. 22-23).

35 Fleming, supra note 26 at 201 . In such circumstances, the issue of apportionment does not arise. Each defendant is liable only for the loss she created; she is not subject to a claim for contribution by the other wrongdoer.

$36 \quad$ Ibid. at 202

37 At trial, Boyd $\mathrm{J}$. treated the bulk of the plaintiff's losses on the basis that they arose subsequent to the Fitness World incident. However, she also recognized that Athey was required to miss four days of work following the first motor vehicle accident and consequently lost $\$ 900$ in wages. Consistent with the notion of divisible injuries, she held that the first defendant was solely and fully liable for that amount (Athey v. Leonati (B.C.S.C.), supra note 2 at para. 26). Major J. did not disturb that finding. 
test invariably remains useful. For the sake of clarity, however, three situations must be distinguished.

\section{(i) Tortious Cause Followed By Non-Tortious Cause}

In Athey v. Leonati, the defendants sought to avoid liability by drawing an analogy to cases in which the claimant, having suffered a wrongful loss as a result of the wrongdoer's tortious conduct, subsequently experiences a pre-trial, non-tortious event independently capable of producing the same loss. In the leading case of Jobling v. Associated Dairies $L t d^{38}$ the defendant carelessly caused the plaintiff to suffer a slipped disc in his back. As a result of the accident, the plaintiff was partially incapacitated and was required to take up a less strenuous form of employment. Before trial, the plaintiff developed a back condition known as spodylotic myelopathy that resulted in total incapacitation and prevented him from working at all. That condition was of non-tortious origin and was entirely unrelated to the initial injury. The House of Lords held that the defendant was liable only for the losses resulting from the slipped disc and incurred prior to the onset of the later condition. ${ }^{39}$ Lord Keith reasoned that:

[w] hile it is logically correct to say that ... the original tort and the supervening event may be concurrent causes of incapacity, that does not necessarily ... provide the correct solution. In the case of supervening illness, it is appropriate to keep in view that this is one of the ordinary vicissitudes of life, and when one is comparing the situation resulting from the accident with the situation had there been no accident, to recognise that the illness would have overtaken the plaintiff in any event, so that it cannot be disregarded in arriving at proper compensation, and no more than proper compensation. ${ }^{40}$

As Major J. indicated in Athey v. Leonati, ${ }^{41}$ that result is entirely defensible on the basis of the "restoration" and "vicissitudes" principles. The aim of tort law is to place the plaintiff in the position that he would have enjoyed if the defendant had not acted culpably. The claimant is not entitled to compensation for all losses that follow the commission of a wrong; rather, his entitlement extends only to those losses that he would not have suffered if he had not been the victim of tortious behaviour. It follows that he cannot recover with respect to losses that, regardless of the defendant's conduct, he suffered by means of non-tortious factors. ${ }^{42}$ As a matter of fairness, that seems

Supra note 21.

More colourfully, in Leschke v. Jeffs, damages for loss of earning capacity resulting from an accident were reduced to reflect the fact that the plaintiff was imprisoned prior to the civil trial: [1955] Q.W.N. No. 67. See also Lankenau v. Dutton (1991), 7 C.C.L.T. (2d) 42 (B.C.C.A.) (plaintiff dying of non-tortious cause before trial).

Jobling, supra note 21 at 815.

(S.C.C.), supra note 2 at $472-73$ (paras. 31-33).

He can, however, recover to the extent (if any) that the initial tortious cause created a loss that would not also have been created by the subsequent non-tortious cause. Thus, in Penner v. Mitchell, the defendant carelessly caused the plaintiff to suffer an injury that required her to miss thirteen months of work. During the period of recuperation, the plaintiff developed an entirely unrelated heart condition that would have necessitated a three month absence from her job in any event. Damages were awarded for a ten month period: (1978), 89 D.L.R. (3d) 343 (Alta. S.C. (A.D.)) [hereinafter Penner]. 
correct. Thus, in Jobling, even if the defendant had not caused the slipped disc, the plaintiff would have suffered the same loss and that loss would have been incompensable. It would be difficult to justify a rule that allowed the claimant to improve his position simply because the defendant, fortuitously, earlier had inflicted the same loss. ${ }^{43}$

Of course, as Major $\mathrm{J}$. noted, the issue of multiple sufficient causation did not properly arise in Athey v. Leonati. ${ }^{44}$ As found by the trial judge, the disc herniation was the combined result of the defendants' tortious negligence and the plaintiff's non-tortious, pre-existing susceptibility to injury. The evidence did not support the proposition that each (or, indeed, either) cause independently was capable of producing the injury.

\section{(ii) Non-Tortious Cause Followed By Tortious Cause}

The analysis is slightly different, but the result the same, when a non-tortious cause precedes (rather than follows) a tortious cause. In such circumstances, the "take your victim" principle (rather than the "vicissitudes" principle) combines with the "restoration" principle to deny relief. Pryor v. Bains is illustrative. ${ }^{45}$ As a result of undergoing a large number of surgical procedures over a sixteen year period, the plaintiff developed an emotional vulnerability to the psychological trauma of any accident, however slight. Four months prior to the accident that formed the subject matter of her suit, she non-tortiously suffered a neck injury ${ }^{46}$ that triggered that susceptibility and rendered her unemployable. She then was involved in a minor motor vehicle collision caused by the defendant's carelessness. As a result of that incident, she experienced lower back pain that she claimed prevented her from working. The trial judge held that that pain, while organic in origin, was primarily a function of her emotional makeup. And because the earlier, non-tortious event had already translated the plaintiff's psychological susceptibility into a disability, he held that she was entitled to recover only 25 percent of her damages. ${ }^{47}$

It appears, however, that the plaintiff in such circumstances is entitled to compensation from the defendant if the loss in question arises from property damage, rather than personal injury (Sunrise, supra note 11). That distinction may be defensible on the basis that the losses attendant on property damage occur immediately, whereas those attendant upon personal injury are of a continuing nature. Consequently, it has been argued that in the latter situation, but not the former, the subsequent non-tortious cause remains causally relevant (Cooper-Stephenson, supra note 22 at 789, 792-93). As the focus of the present discussion is on Athey v. Leonati specifically, and personal injury cases generally, the issue of property damage will not be addressed further. (S.C.C.), supra note 2 at $472-73$ (paras. 31-33).

$45 \quad$ (1986), 69 B.C.L.R. 395 (C.A.) [hereinafter Pryor]. See also Martin v. Jordan (1988), 31 B.C.L.R. (2d) 266 (C.A.); Benson v. Jamieson (1991), 106 N.S.R. (2d) 335, aff d (1993), 117 N.S.R. (2d) 347 (C.A.). Cf. Nygaard v. Gosling, [1988] B.C.J. No. 2026 (S.C.) (QL).

While the plaintiff suffered that injury as a result of an altercation with a patient at a psychiatric institution where she worked, there was no suggestion in the court's judgment that that incident was of a culpable character. Accordingly, it was treated as being non-tortious.

47 The damages awarded represented the losses caused by the tortious event that would not have occurred by reason of the non-tortious event alone. 
It appears that the appropriate course in this case is to determine the damages which would have been awarded had the plaintiff's present condition resulted from a single cause for which a defendant were liable and to award a portion of that amount equivalent to the portion of the plaintiff's disability which can fairly be attributed to this defendant's negligence. ${ }^{48}$

Carrothers J.A., speaking for the British Columbia Court of Appeal, affirmed that decision.

I have not been persuaded that the trial judge misconstrued the evidence that the appellant was, at the time of the accident, using the pain of her neck injury as a psychological crutch and, following the accident, transferred the psychological crutch to the pain in the lumbar area of her back. ${ }^{49}$

That result was justifiable from either party's perspective. The plaintiff's entitlement under the "restoration" principle merely was to be placed in the position that she occupied before being subject to the wrong. In the circumstances, of course, she had suffered much of her total loss even before the defendant's tort took effect. Moreover, the initial loss occurred as a result of a non-tortious, and hence non-compensable, factor. Consequently, regardless of the defendant's wrong, the claimant would have faced a hardship and she would have been required to meet that hardship on the basis of her own resources. The court's refusal to award compensation accordingly did her no harm. The denial of relief also was appropriate from the defendant's perspective. Because he was required only to restore the plaintiff to the position that she would have occupied if he had not acted wrongfully, he was entitled to take his victim as he found her. And when he found her, she already was subject to a non-compensable loss. Consequently, he was not obligated to make reparation even though his actions alone would have been sufficient to cause the same loss.

\section{(iii) Simultaneous Non-Tortious And Tortious Causes}

The rule applicable to cases in which a claimant simultaneously was subject to a tortious cause and a non-tortious cause, each of which independently was sufficient to produce the loss in question, is seldom invoked, but surely indisputable. That there are few cases on point is not surprising; the requisite sequence of events is highly unlikely. Nevertheless, it is clear that recovery once again is unavailable to the extent that the causal factors overlap; the defendant is liable only if the tortious cause created additional losses or exacerbated the losses that would have resulted from the non-tortious event alone. ${ }^{50}$ While they pertain to property damage, rather than personal

Rumley v. Hewison, Victoria No. 0400/76 (B.C.S.C.), Taylor J., affd (30 September 1981), (B.C.C.A.) [unreported]; quoted in Pryor, supra note 45 at 399.

49 Pryor, ibid. at 400.

so When discussing "multiple sufficient causes," the text of this article addresses situations involving "additional" causes. In such circumstances, both of the causal factors in question actually occurred and affected the plaintiff. A contrast must be drawn to situations involving "alternative" causes. In those circumstances, only the first causal factor actually occurred and affected the plaintiff; the second would have done so if the sequelae of the first had not prevented such an event. In the interests of brevity and clarity, consideration of "alternative" causes will be confined to a series of notes (infra at notes $58,59,79,81,91$ ). 
injury, observations made in Kingston v. Chicago \& N.W. Railway Co. ${ }^{51}$ are apposite. The plaintiff's property was destroyed by a conflagration that was the combined result of two fires. The first fire was caused by sparks that the defendant carelessly allowed its locomotive to emit and the second was caused by some unknown human act; ${ }^{52}$ alone, either would have been sufficient to cause the damage in question. Because the latter was presumed culpable, the court held the defendant fully liable for the plaintiff's loss. ${ }^{53}$ In dicta, however, it recognized that the plaintiff would have been denied recovery if one of the two blazes had been attributable to natural causes or some other non-culpable factor. ${ }^{54}$

The applicable rule, then, essentially is the same whether a non-tortious cause occurs after, before or simultaneously with a tortious cause. While the "take your victim" principle and the "vicissitude" principle provide conclusive guidance in the first two situations, the "restoration" principle is sufficient in any event. The relevant question invariably is whether or not the plaintiff's position was worsened by reason of the defendant's wrong; if he would have suffered the same loss by reason of a non-compensable factor regardless of the tort, he is not entitled to redress. Accordingly, it is not strictly necessary to determine the sequence of events if one of the causes is non-tortious.

\section{b. Tortious Causes}

The same is not true when all of the relevant causal factors are tortious in character. In such circumstances, timing is critically important.

For present purposes, an apt illustration is found in the remarkable case of Dillon v. Twin State Gas \& Electric Co., 163 A. 111 (N.H. 1932). The defendant, knowing that local children frequently climbed to the top of a bridge, carelessly placed its electrical wires in a position where they might be touched. While playing upon the bridge, a boy lost his balance and, while falling, instinctively grabbed onto the wire. The court found that he was electrocuted and died immediately. However, the evidence also indicated that if he had not died in that manner, he would have been killed (or at least maimed) upon hitting the ground. Arguments of varying degrees of merit could be made to the effect that, with respect to the tortious cause, the non-tortious cause occurred first (because the boy fell before he grabbed the wire), second (because the boy did not hit the ground until after he grabbed the wire), or simultaneously (because, practically speaking, the interval between the two events was too brief to be relevant). While the court correctly preferred the middle option, the legal result would have been the same in any event. If the boy's death had not been caused by the defendant's carelessness, it alternatively would have been caused by the fall. And because the boy therefore was doomed as a result of a non-culpable, and hence non-compensable, factor, the defendant's wrong could not give rise to relief.

211 N.W. 913 (Wisc. 1927) [hereinafter Kingston].

It is irrelevant that the two fires did not start simuitaneously. The cause of action in negligence was not complete until damage occurred and, in that regard, the effect of each fire was simultaneous.

That situation is considered below under the heading of "simultaneous tortious causes": Part $\operatorname{III}(\mathrm{A})(2)(\mathrm{b})(\mathrm{i})$.

Supra note 51 at 914-15. 
[VOL. XXXV, NO. 4 1997]

\section{(i) Simultaneous Tortious Causes}

Like situations involving simultaneous tortious and non-tortious causes, those involving simultaneous tortious causes are unusual, but uncontroversial. While supportive case law is sparse, ${ }^{55}$ there is no doubt, for example, that both of the defendants would be held fully liable for all of the resulting losses ${ }^{56}$ if they simultaneously fired fatal shots through the plaintiff's heart. A court would not be dissuaded from such a result merely because the "but for" test would indicate that neither wrongdoer was responsible for the victim's death. ${ }^{57}$ Rather, on the basis of a common sense application of the "restoration" principle, it would seek to place the victim in the position that he would have enjoyed if he had not been wronged. And in that regard, it is irrelevant that more than one wrong was involved..$^{58}$ Indeed, it would be an intolerable embarrassment to justice if the victim's legal rights were detrimentally affected by the fact that he suffered not one, but two, torts.

\section{Successive Tortious Causes}

The most contentious causal problem arises when the plaintiff is the victim of successive torts, each of which occurs before trial and each of which independently was capable of producing the relevant loss. Once again, the "but for" test must be disregarded as intolerably suggesting that liability should attach to neither factor. It is clear that the plaintiff must enjoy recovery; the source of compensation, however, is somewhat unclear. ${ }^{59}$ Three possibilities present themselves: ${ }^{60}$ (i) the first tortfeasor might be held solely liable on the ground that the second is entitled to "take her victim" as she finds him; (ii) the second tortfeasor might be held solely liable on the ground

As previously discussed above, Kingston, ibid. provides a precedent with respect to cases involving property damage: above at Part III(A)(2)(a)(iii).

Apportionment legislation would allow each defendant to seek contribution from the other so as to split the burden of liability appropriately (see e.g. Tort-feasors Act, supra note 33).

The first defendant might argue that "but for" her actions, the deceased would have suffered the same fate because of the second defendant's wrong; the second defendant equally might argue that "but for" her actions, the deceased would have suffered the same fate because of the first defendant's wrong.

Returning to the notion of "alternative," as opposed to "additional," causes (supra note 50), liability clearly could not be imposed upon one defendant on the basis that she would have shot the plaintiff through the heart at the precise moment that the other defendant actually did so, if the latter had not acted in the manner that she did. As generally is true in law, potential wrongdoers are entitled to the benefits of moral luck. No matter how careless or malicious her actions, a person need not provide compensation if, in fact, she caused no harm.

Returning once again to the issue of "alternative," as opposed to "additional" causes (supra note 50), it is clear that a defendant cannot avoid liability by arguing that if she had not tortiously inflicted a loss upon the plaintiff, another actor would have done so. To hold otherwise would offend the "restoration" principle. In such circumstances, the plaintiff indisputably must enjoy recovery from some source. However, because the potential author of the alternative cause never actually affected the claimant, she could not possibly be held responsible. Obviously, then, the defendant must provide the compensation.

A fourth possibility would allow the first defendant the benefit of the "vicissitudes" principle and the second defendant the benefit of the "take your victim" principle. However, as the result would deny the plaintiff relief from either wrongdoer, and hence offend the "restoration" principle, it obviously is unacceptable and need not be examined further. 
that the first is entitled to rely upon the "vicissitudes" principle; and (iii) both tortfeasors might be held jointly liable. All three approaches enjoy at least some support in the case law.

Baker v. Willoughby ${ }^{61}$ remains the classic case with respect to the approach based on the "take your victim" principle. The defendant carelessly caused a motor vehicle accident that left the plaintiff with a stiff leg. As a result of that injury, the claimant was partially disabled and consequently experienced diminished earning capacity. Before the trial of that action, the plaintiff was shot in the same leg by a thief. The wound was such that the limb had to be amputated, thereby resulting in a further reduction of future income. While the Court of Appeal had accepted the defendant's suggestion that the second injury subsumed the effect of the first, the House of Lords disagreed. Lord Reid explained.

A man is not compensated for the physical injury: he is compensated for the loss which he suffers as a result of that injury. His loss is not in having a stiff leg: it is in his inability to lead a full life, his inability to enjoy those amenities which depend on freedom of movement and his inability to earn as much as he used to earn or could have earned if there had been no accident. In this case, the second injury did not diminish any of these. So why should it be regarded as having obliterated or superseded them?

[A] wrongdoer must take the plaintiff (or his property) as he finds him: that may be to his advantage or disadvantage. In the present case, the robber is not responsible or liable for the damage caused by the [defendant]; he would only have to pay for additional loss to the [plaintiff] by reason of his now having an artificial limb instead of a stiff leg. ${ }^{63}$

While the decision in Baker v. Willoughby occasionally has been criticized, and indeed was questioned by members of the House of Lords in Jobling v. Associated Dairies Ltd. ${ }^{64}$ it undoubtedly represents the approach most commonly taken in Canada. ${ }^{65}$ Thus, damages typically are assessed against the first tortfeasor as if a trial had occurred immediately prior to the second accident. The second defendant is liable only for the creation of additional losses or the exacerbation of existing ones; losses that truly are the product of multiple sufficient causes are the responsibility of the first defendant alone.

Supra note 21.

Ibid. at 492 . Lord Reid, however, recognized that the damages payable by the author of the first injury would have been reduced if the second injury had either: (i) diminished the disabilities or pain resulting from the first; or (ii) shortened the plaintiff's life expectancy and hence the period for which damages would be awarded (at 494).

Ibid. at 493.

Supra note 21 at 802 per Lord Wilberforce.

See e.g. Stene v. Evans (1958), 14 D.L.R. (2d) 73 (Alta. S.C. (A.D.)); Long v. Thiessen (1968), 65 W.W.R. 577 (B.C.C.A.); Hicks v. Cooper (1973), 1 O.R. (2d) 221 (C.A.); Berns v. Campbell (1974), 8 O.R. (2d) 680 (H.C.) (three successive tortious causes); Penner, supra note 42 (dicta); Masson v. Rowan, [1988] 4 W.W.R. 430 (Man. Q.B.) (three successive tortious causes). 
As noted above, while the House of Lords in Baker v. Willoughby gave precedence to the "take your victim" principle, the Court of Appeal had focused instead on the "vicissitudes" principle. ${ }^{66}$ Thus, Harman L.J. stated that "the damage to the left leg caused by the first accident did not survive the second and ... the plaintiff's damages [as against the defendant] must be confined to the period before the amputation of the limb." ${ }^{.67}$ However, having been rejected on appeal by the House of Lords, that approach seldom has found favour since. ${ }^{68}$ The reason may be that it erroneously refers to the injury sustained rather than to the loss suffered. For while it may be appropriate to say that the injury represented by a stiffened leg is obliterated when the same limb subsequently is amputated, the victim's loss of income continues to affect him after the amputation, just as it did before the second wrong took effect. ${ }^{69}$

The third possible approach entails the imposition of joint liability on both tortfeasors with respect to those losses that either wrongful act would have been sufficient to create. $^{70}$ The great benefit of that proposal is that it would best ensure proper compensation of the plaintiff." Baker v. Willoughby again can be used for the purposes of illustration. One suspects that the House of Lords may have favoured the "take your victim" principle (which primarily points to the first wrongdoer) over the "vicissitudes" principle (which primarily points to the second wrongdoer) because the former better facilitated the restoration of the victim on the facts of that case. The

Supra note 21.

67 Ibid. at 483. Potentially, that approach could work a great hardship on a claimant. Consider a situation in which the plaintiff initially earns $\$ 12,000$ per year, spread equally over twelve months. As a result of the first tortfeasor's carelessness, he is injured on January 1st and suffers a 50 percent reduction in earning capacity. On July 1st, before the trial of the first action, the second tortfeasor carelessly injures the plaintiff and thereby renders him totally incapacitated for employment purposes. The first tortfeasor would be liable for $\$ 3000$ because she reduced by half the claimant's ability to earn $\$ 6000$ during the first six months of the year. She would avoid liability for losses occurring after July lst because she would be entitled to rely on the vicissitudes principle. The second tortfeasor, however, might attempt to argue that she should be liable for only $\$ 3000$ on the ground that she in fact incapacitated a person who, but for her wrong, would have earned that amount of employment income during the remainder of the year. If that argument succeeded, the plaintiff would receive a total of only $\$ 9000$ during the year (\$3000 from employment income before July 1 st and $\$ 3000$ in damages from each of the defendants) and therefore would not be restored to the position that he would have enjoyed if he had not been subject to any wrongful behaviour. The Court of Appeal recognized that danger, however, and stated that the second tortfeasor would be liable for $\$ 6000$ on the ground that she tortiously deprived the plaintiff of receiving that amount by way of combined employment income and compensatory relief from the first tortfeasor. It reasoned that the second defendant should be required to take her victim as she found him with respect to both: (i) his ability to receive $\$ 3000$ in income through employment; and (ii) his ability to receive $\$ 3000$ in income through the proxy of damages from the first defendant (ibid. at 480-83). Cf. ibid. at 495-96 (Lord Pearson doubting that the latter could constitute a proper head of recovery). Cf. Griffiths v. Commonwealth (1983) 50 A.C.T.R. 7 (A.C.T.S.C.). Cooper-Stephenson, supra note 22 at 800 .

As always, each defendant would be held solely responsible for losses that she alone caused. For example, in Baker, supra note 21, the first wrongdoer would have been exclusively liable for the losses actually incurred prior to the second incident.

A subsidiary benefit of the joint liability approach is that it would obviate the need for proof as to which of two successive wrongs occurred first. 
author of the first cause, the defendant, had been brought to court; the author of the second cause, the robber, had not been identified. Of course, the facts of a future case might occur in the opposite order; the unidentifiable tortfeasor might inflict the first injury and the identifiable tortfeasor the second. ${ }^{72}$ If so, the House of Lords' decision would create a hardship for the plaintiff because his only practical source of compensation would be entitled to take her victim as she found him. Consequently, by adopting either the "take your victim" principle or the "vicissitudes" principle, the courts invite the danger of prejudicing a claimant by reason of the fact that he suffered two torts, rather than one. In doing so, they also run the risk of frustrating the aim of the "restoration" principle. Accordingly, the law arguably should allow the victim of successive sufficient causes to recover all of his damages from either wrongdoer, ${ }^{73}$ just as it does in cases of simultaneous, sufficient causes that are tortious in origin. ${ }^{74}$ As yet, however, precedential support for that proposition is slight. ${ }^{75}$

Before concluding the discussion of multiple sufficient causation, brief reference must be made to two outstanding points. The first pertains to the case in which both the defendant's tortious conduct and the plaintiff's own contributory negligence independently was capable of producing the relevant loss. Talk of the claimant's "negligence" potentially is misleading in so far as it may suggest that the situation is one of multiple tortious causes. In fact, the plaintiff's contribution should be characterized as non-tortious, with the result that recovery ought to be denied. ${ }^{76}$ Returning to first principles, the reason is obvious. Pursuant to the "restoration" principle, the claimant is entitled to be placed in the position that he would have enjoyed if the defendant had not acted wrongfully. In the circumstances, the plaintiff would have non-compensably suffered the relevant loss regardless of the tortfeasor's conduct. Accordingly, he has no claim to relief.

The final point arises from the fact that while relief invariably is denied if one of the sufficient causes is non-tortious in origin, it invariably is available (from at least one defendant) if both causes are tortious. Occasionally, the plaintiff may bring an action

Alternatively, while both tortfeasors might be identifiable, the first might be judgment-proof, whereas the latter may be supported by a large insurance fund.

As between themselves, the tortfeasors would have the right to seek contribution from each other so as to effect an appropriate distribution of the burden of liability (supra note 56).

Above at Part III(A)(2)(b)(i). If a court refused to adopt the joint liability approach, a claimant might argue that the causal factors occurred so closely in time that they should be considered simultaneous. While conceptually flawed, the argument would have the attraction of best ensuring complete recovery from either or both of two wrongdoers.

See e.g. Sunrise, supra note 11 at 39 per McLachlin J. (plaintiff's contributory negligence); Bourke v. Wells (1991), 82 D.L.R. (4th) 574 (N.B.C.A.); Harwood v. Wyken Colliery Co., [1913] 2 K.B. 158 at 169 (C.A.) (dicta); Carslogie Steamship Co. v. Royal Norwegian Government, [1952] A.C. 292 (H.L.). See also U. Wagner, "Successive Causes and the Quantum of Damages in Personal Injury Cases" (1972) 10 Osgoode Hall L.J. 369 at 389; Cooper-Stephenson, supra note 22 at 798-99.

Above at Part III(A)(2)(a). In contrast, if each party's contribution was necessary for the production of the loss, the situation is one of multiple insufficient causes and the plaintiff is entitled to damages, albeit reduced to reflect the effect of his own contributory negligence (above at Part III(A)(1)(a)). 
against the author of one cause without knowing whether or not the other cause also was culpable in origin. In such circumstances, a question arises as to which set of rules applies. While the plaintiff generally must prove all parts of his claim, the courts occasionally are willing to assume in his favour that both causes were tortious in character. ${ }^{77}$ The matter remains open to debate, however, and claimants should try, if at all possible, to ensure that all relevant parties appear in the same action.

\section{B. THIN SKULLS AND CRUMBLING SKULLS}

Invoking the "thin skull" and "crumbling skull" doctrines, the defendants in Athey v. Leonati sought to reduce their measure of liability on the ground that the plaintiff suffered from a pre-existing weakness in his back and hence was susceptible to injury. They argued that because the latent condition might have been triggered by some other event in the future, they should not be held fully liable for the plaintiff's loss merely because the motor vehicle accidents fortuitously provided a preemptive catalyst. Rather, they suggested that the claimant should be limited to relief for such losses that flowed from the motor vehicle accidents and that could be expected to accrue prior to the occurrence of the hypothetical event.

As Major J. recognized, that argument theoretically was sound. The reason can be seen by once again returning to basics. First, the "restoration" principle requires the defendant to place the plaintiff in the position that he would have enjoyed if she had not committed a wrong; she is not allowed to subject him to a loss, but neither is she obliged to improve his lot in life. ${ }^{78}$ Second, while the "take your victim" principle does not permit the defendant to avoid liability merely because the plaintiff was especially vulnerable to injury, it does relieve her of responsibility to the extent that the claimant's susceptibility manifested itself in the form of a loss prior to the commission of the tort. And finally, the "vicissitudes" principle reduces the tortfeasor's liability to the extent that the plaintiff experienced a sufficient, non-tortious ${ }^{79}$ cause after she committed her wrong, but before trial.

The "thin skull" doctrine is an application of the first branch of the "take your victim" principle. To use the language of the metaphor, even if a person of normal fortitude would withstand a certain blow to the head without serious injury, the defendant is fully liable for the unexpectedly serious consequences of her actions if her

Thus, although he had not been identified or brought to justice, the gunman in Baker, supra note 21 , safely was assumed to have acted tortiously (discussed above, text accompanying note 61). So too the second fire in Kingston was presumed tortious (discussed supra at note 51). Hart \& Honoré suggest that the identified tortfeasor should bear the burden of proving that the other cause was non-tortious in origin (supra note 1 at 248).

Athey v. Leonati (S.C.C.), supra note 2 at 473 (paras. 34-35).

That is true whether the second (non-tortious) cause was "additional" or "alternative" (above at Part III(A)(2)(a)(ii) and note 50). To reiterate, however, as the law currently stands, the initial tortfeasor is not entitled to rely upon the "vicissitudes" principle if the second sufficient cause was tortious (above at Part III(A)(2)(b)(ii)). That holds true with respect to both "additional" and "alternative" causes (supra note 50). 
victim happens to experience catastrophic loss because he has an unusually thin skull. ${ }^{80}$ Similarly, the fact that Jon Athey suffered from a latent disposition to back problems simply was bad luck for the careless drivers in Athey v. Leonati; they were required to take him as they found him.

The "crumbling skull" doctrine also is an application of the three guiding principles. In essence, it combines the "take your victim" and "vicissitudes" principles and projects them into the future. While a tortfeasor must accept her victim's frailties, she need not relieve him of losses that he non-tortiously ${ }^{81}$ would have suffered during the ordinary course of his life. As discussed above, that is true with respect to vicissitudes occurring before trial ${ }^{82}$; it also is true of events occurring after trial. Thus, if the claimant's skull was not merely "thin," but "crumbling" and likely to shatter at some point in the future regardless of any wrongdoing, the defendant is held liable only for the fact that she hastened or compounded the misfortune. ${ }^{83}$ Stated with reference to the "restoration" principle, then, the plaintiff is not entitled to saddle the defendant with the burden of otherwise non-compensable losses that he would have suffered in any event. By reducing the wrongdoer's measure of liability to reflect such prospects, the court effectively re-constructs the claimant's pre-tort fate and compels him to remain personally responsible for meeting the innocent exigencies of his own life.

Although theoretically sound, the defendants' argument in Athey v. Leonati was factually untenable. While characterizing the "crumbling skull" submission as the defendants' strongest, Major J. noted that there simply was "no finding of any measurable risk that the disc herniation would have occurred without the accident, and

Dulieu v. White \& Sons, [1901] 2 K.B. 669; Lapointe v. Parent, [1952] I S.C.R. 376; Janiak v. Ippolito, [1985] 1 S.C.R. 146 at 152-58.

As Prowse J.A. explained in Penner, supra note 42, the "crumbling skull" doctrine cannot be based on the possibility that the plaintiff tortiously might suffer the same loss at some point in the future.

My reason for concluding that future contingencies arising in culpable circumstances should not be taken into account in assessing damages such as prospective loss of income, is, because if that were done, the plaintiff would receive less than full compensation from the two wrongdoers. This would follow as there would be a deduction from the first loss because of the contingency that the second culpable event might occur and there would be a deduction from the second claim as the first culpable incident had occurred. The result of both deductions would produce a result that [Baker, supra note 21] sought to avoid. Such a result would infringe the dominant rule applied in assessing damages as the injured person would then receive less than full compensation for the injuries that he had sustained.

Returning once again to the notion of "alternative," as opposed to "additional" causes (supra note 50), it is even clearer that the "crumbling skull" doctrine cannot be applied with respect to a future injury that might have been sustained by means of some tortious cause if the defendant had not already inflicted the loss. Because the second tortious cause ex hypothesi will never actually occur, the plaintiff would be deprived of proper restoration if the author of the first tortious cause was not held fully liable. Above at Part III(A)(2)(a)(ii).

Graham v. Rourke (1990), 74 D.L.R. (4th) 1 (Ont. C.A.); Millett v. McDonald's Restaurants of Canada Ltd. (1984), 29 Man. R. (2d) 83 (Q.B.); Malec v. JC Hutton Proprietary Lid. (1990) 169 C.L.R. 638 (Aust. H.C.); Cutler v. Vauxhall, [1971] 1 Q.B. 418 (C.A.). 
there was therefore no basis to reduce the award to take into account any such risk." 84 Athey's back was "thin," but not "crumbling."

\section{LOSS OF CHANCE}

The defendants' final submission in Athey v. Leonati was their most adventurous. They suggested that their careless driving merely increased the risk that the plaintiff would suffer a herniated disc and that they accordingly should be liable only for diminishing his chances of avoiding the resulting losses. Major J. tersely dismissed that argument on the ground that it was unsupported by the evidence.

The trial judge made no findings suggesting that the injury was loss of a chance to avoid a disc herniation. The finding made at trial was that the accidents contributed to the actual disc herniation itself. $^{85}$

The "loss of chance" doctrine is highly controversial and a thorough examination of it lies well beyond the scope of this article.$^{86}$ Nevertheless, it is possible very briefly to indicate why it could not possibly have applied on the facts of Athey v. Leonati. The doctrine holds that a claimant occasionally should be permitted recovery despite failing to satisfy the usual burden of establishing on a balance of probabilities that the tortfeasor's conduct caused him to suffer a loss. If able to prove that the defendant's actions prevented him from enjoying a significant opportunity (beyond the de minimis range) to gain a benefit or avoid a detriment, the plaintiff may be granted relief, discounted to reflect the likelihood of the relevant chance. ${ }^{87}$ However, as Major J. noted elsewhere in his decision, ${ }^{88}$ a fundamental distinction must be drawn between the manner in which the law approaches two sets of inquiries: (i) those that pertain either to what might happen in the future or to what might have happened in the past if not precluded from doing so by actual events; and (ii) those that pertain to what did happen in the past. As to the former, he stated that

Athey v. Leonati (S.C.C.), supra note 2 at 474 (para. 56).

Ibid. at 474 (para. 38).

See e.g. J.G. Fleming, "Probabilistic Causation in Tort Law" (1989) 68 Can. Bar Rev. 661; Cooper-Stephenson, supra note 22 at 764-76; J.H. King, "Causation, Valuation, and Chance in Personal Injury Torts Involving Preexisting Conditions and Future Consequences" (1981) 90 Yale L.J. 1353.

Though responding to a contractual claim, the principles articulated in the leading case of Chaplin v. Hicks apply equally in tort: [1911] 2 K.B. 786 (C.A.). The defendant wrongfully breached a contract and thereby deprived the plaintiff of being chosen as one of the winners of a beauty contest. While the plaintiff could not prove that she would have been among the winners of the contest if the defendant had not acted wrongfully, the Court of Appeal upheld the jury's decision to award damages, calculated to reflect the plaintiff's likelihood of having been selected. Cf. Laferrière v. Lawson, [1991] I S.C.R. 541; Hotson v. East Berkshire Area Health Authority, [1987] 2 All E.R. 909 (H.L.); Sellars v. Adelaide Petroleum NL (1994) 179 C.L.R. 332 (Aust. H.C.); Takaro Properties Lid. v. Rowling, [1986] 1 N.Z.L.R. 22 (C.A.).

Major J. provided the following observations in response to the defendants' argument that the trial judge's assessment of the probability of causation was analogous to the manner in which courts assess probabilities when reducing damages to account for contingencies: Athey v. Leonati (S.C.C.), supra note 2 at 470-71 (paras. 26-30). On the issue of contingencies, see supra note 22. 
[h]ypothetical events (such as how the plaintiff's life would have proceeded without the tortious injury) or future events need not be proven on a balance of probabilities. Instead, they are simply given weight according to their relative likelihood.... For example, if there is a 30 per cent chance that the plaintiff's injuries will worsen, then the damage award may be increased by 30 per cent of the anticipated extra damages to reflect that risk. A future or hypothetical possibility will be taken into consideration as long as it is a real and substantial possibility and not mere speculation.

As to the latter type of inquiry, he stated that,

[b]y contrast, past events must be proven, and once proven they are treated as certainties. In a negligence action, the court must declare whether the defendant was negligent, and that conclusion cannot be couched in terms of probabilities. Likewise, the negligent conduct either was or was not a cause of the injury. The court must decide, on the available evidence, whether the thing alleged has been proven; if it has, it is accepted as a certainty. ${ }^{89}$

The relevant question in Athey v. Leonati pertained to the causal effect of the defendants' carelessness: a past fact. As such, it fell into the latter category of inquiry and stood to be resolved on the usual standard of the balance of probabilities. As the trial judge was satisfied that the motor vehicle accidents probably did contribute to the disc herniation, that causal relationship was treated as a certainty and the claimant was entitled to full recovery. Accordingly, there was no scope for reducing the award on the basis of the "loss of chance" doctrine. ${ }^{90}$

\section{CONCLUSION}

The issue of factual causation provides an occasionally fertile source of confusion and error in tort law. As initially occurred in Athey v. Leonati, difficulties typically arise when a court loses sight of the fundamental rules that guide the availability and quantification of relief, or when it fails properly to appreciate the nature of the situation with which it is faced. By returning to basics, the Supreme Court of Canada's unanimous decision in Athey v. Leonati accordingly serves as a useful restatement. The ratio of that judgment is, of course, limited in scope: in cases of multiple insufficient causation, the tortfeasor cannot avoid liability on the ground that one of the necessary contributing causes emanated from the claimant. However, Major J's general observations, including those in dicta, easily extend to the resolution of other, more complicated, cases as well. As this article has attempted to demonstrate, the determination of seemingly complex issues is greatly simplified if attention is focused upon the "restoration," "take your victim" and "vicissitudes" principles, and if

Ibid. at 470-71 (paras. 27-28) [citations omitted]. See also Mallett v. McMonagle, [1970] A.C. 166 (H.L.).

90 Perhaps the matter more clearly can be explained on the basis of an analogy. Consider a situation in which the parties are engaged in skeet shooting. The defendant negligently points her loaded weapon at the plaintiff and pulls the trigger to horrific consequences. No court would ever reduce the tortfeasor's measure of liability on the ground that her carelessness merely increased the victim's risk of being shot. Such reasoning invariably would deprive claimants of full restoration. 
distinctions are drawn between: (i) tortious and non-tortious causes, (ii) sufficient and insufficient causes, and (iii) simultaneous and successive causes." 